\title{
PESERTA DIDIK DALAM PANDANGAN NATIVISME, EMPIRISME, DAN KONVERGENSI
}

\author{
MUSDALIFAH \\ Fakultas Tarbiyah dan Keguruan UIN Alauddin Makassar \\ Jl. HM. Yasin Limpo No. 36 Makassar \\ Email: gaffarmusdalifah@gmail.com
}

\begin{abstract}
:
To achieve the objectives of learning in the classroom many things are needed, because the process is a complex phenomenon. One of the influences is the educator's understanding of the existence of students. Educators must know the views of various streams of education about students. This paper focuseses on nativism, empiricism, and convergence in understanding students. The flow of nativism holds that the development of students is determined from birth. This stream believes that human development is determined by its defenders. Environmental factors have less influence on children's education and development. Therefore, the results of education are determined by birth-born talent. The flow of empiricism assumes that children born into the world are like white paper. White paper will have patterns and writing that are scratched by the environment. Educators as external factors play a very important role, because educators provide an educational environment for children, and children will receive education as experience. This experience will shape the behavior, attitudes, and character of the child based on the educational goals.
\end{abstract}

Keywords: Nativism, Empirism, Convergence

\section{PENDAHULUAN}

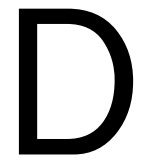
iantara komponen terpenting dalam pendidikan dalah peserta didik. Dalam perspektif pendidikan, peserta didik merupakan subyek dan obyek. Oleh karena aktivitas kependidikan tidak akan terlaksana tanpa keterlibatan peserta didik didalamnya. Pengertian yang utuh tentang konsep pserta didik merupakan salah satu fakor yang perlu diketahui dan dipahami oleh seluruh pihak khususnya yang terlibat secara langsung dalam pendidikan. Tanpa pemahaman yang utuh dan kompershensif terhadap peserta didik, sulit rasanya bagi pendidik untuk dapat menghantarkan peserta didiknya dalam tujuan yang diinginkan (Nizar, 2002:47).

Tujuan yang diinginkan tersebut dapat diaplikasikan dalam proses belajar/mengajar. Proses belajar/mengajar adalah fenomena yang komplek. Segala sesuatunya berarti, setiap kata, pikiran, tindakan dan asosiasi dan sampai sejauh mana kita mengubah lingkungan, presentasi dan rancangan pengajaran, sejauh itu pula proses belajar berlangsung. Dalam hal ini pengaruh dari peran seorang pendidik sangat besar sekali. Dimana keyakinan seorang pendidik atau pengajar akan potensi manusia dan kemampuan semua peserta didik untuk belajar dan berprestasimerupakan suatu hal yang penting diperahtikan. Aspekaspek teladan mental pendidik atau pengajar berdampak terhadap iklim belajar 
dan pemikiran peserta didik yang di ciptakan pengajar. Pengajar harus mampu memahami bahwa perasaan dan sikap peserta didik akan terlihat dan berpengaruh kuat pada proses belajarnya.

Dalam paradigm pendidikan Islam, peserta didik merupakan orang yang belum dewasa dan memiliki sejumlah potensi (kemampuan) dasar yang masih perlu dikembangkan. Di sini, peserta didik merupakan makhluk Tuhan yang memiliki Fitrah jasmani maupun rohani yang belum mencapai taraf kematangan baik bentuk, ukuran maupun perimbangan pada bagian-bagian lainnya. Dari segi rohaniah ia memiliki bakat, memiliki kehendak, perasaan dan pikiran yang dinamis dan perlu dikembangkan (Langgulung, 2003:79).

Dalam mempelajari perkembangan manusia diperlukan adanya perhatian khusus mengenal hal-hal sebagai berikut: 1) Proses pematangan, khususnya pematangan fungsi kognitif. 2) Proses belajar. 3) pembawaan atau bakat. Ketiga hal-hal ini berkaitan erat satu sama lain dan saling berpengaruh dalam perkembangan kehidupan manusia tak terkecuali peserta didik (Syah, 2008:43). Apabila fungsi kognitif, bakat dan proses belajar seorang peserta didik tersebut mengalami proses perkembangan kehidupan secara mulus. Akan tetapi, asumsi yang menjanjikan seperti ini sebenarnya belum terwujud, karena banyak faktor yang berpengaruh terhadap proses perkembangan peserta didik dalam menuju cita-cita bahagianya.

Adapun mengenai faktor-faktor yang memepengaruhi perkembangan peserta didik, para ahli berbeda pendapat lantaran sudut pandang dan pendekatan mereka terhadap eksistensi peserta didik tidak sama.

\section{PEMBAHASAN}

\section{Pandangan Pendidikan terhadap Peserta Didik}

Sebagaimana pemakalah kemukakan latar belakang diatas, bahwa peserta didik merupakan subyek dan obyek pendidikan. Pendidikan ibarat uang logam, selalu memiliki dua sisi yakni, satu pihak bertugas mengajar (pendidik), sedangkan pihak lain tugasnya belajar (peserta didik). Peserta didik merupakan salah satu dari dua sisi tersebut, yang memiliki tugas menerima konsep pendidikan (Isa, 1994:79).

Melalui paradigma di atas menjelaskan bahwa peserta didik merupakan subyek dan obyek pendidikan yang memerlukan bimbingan orang lain (pendidik) untuk membantu mengarahkan mengembangkan potensi yang dimilikinya, serta membimbingnya menuju kedewasaan. Sebab potensi itu tidak akan mengalami perkembangan yang optimal tanpa adanya bimbingan pendidik. Karena itu pemahaman terhadap peserta didik sangat perlu untuk diketahui oleh pendidik, karena melalui pemahaman tersebut akan membantu pendidik dalam melaksanakan tugas dan fungsinya melalui berbagai aktivitas kependidikan.

Karena itu perlu diperjelas beberapa diskripsi tentang hakekat peserta didik dan implikasinya menurut pendidikan Islam, yaitu: 
1. Peserta didik bukan merupakan meniatur orang dewasa, akan tetapi memiliki dunianya sendiri

2. Peserta didik adalah manusia yang memiliki diferensi prioderasi perkembangan dan pertumbuhan

3. Peserta didik adalah manusia yang memiliki kebutuhan baik yang menyangkut kebutuhan jasmani maupun rohani yang harus dipenuhi

4. Peserta didik adalah makhluk Allah yang memiliki perbedaan individu (differensisasi individual), baik yang disebabkan oleh faktor pembawaan maupun lingkungan dimana dia berada.

5. Peserta didik merupakan result dari dua unsur utama, yaitu jasmani dan rohani. Unsur jasmani memiliki daya fisik yang menghendaki latihan dan pembiasaan yang dilakukan melalui proses pendidikan. Sementara unsur rohaniah memiliki dua daya akal dan dan daya rasa. Untuk mempertajam daya akal, maka proses pendidikan hendaknya diarahkan untuk mengasa daya inteletualitasnya melalui ilmu-ilmu rasional. Adapun untuk mempertajam daya rasa dapat dilakukan melalui pendidikan akhlak dan Ibadah. Menurut penulis istilah daya sesuai dengan penemuan mutakhir daya-daya tersebut adalah kecerdasan intelektual (IQ), kecerdasan emosional (EQ) dan kecerdasan Spritual (SQ)

6. Peserta didik adalah manusia memiliki potensi fitrah yang dapat dikembangkan dan berkembang secara dinamis (Nizar, 2002:48-50).

\section{Faktor-faktor yang Memengaruhi Perkembangan Peserta Didik}

Adapun mengenai faktor-faktor yang memengaruhi perkembangan peserta didik, para ahli berbeda pendapat lantaran sudut pandang dan pendekatan mereka terhadap eksistensi peserta didik tidak sama. Untuk lebih jelasnya berikut ini pemakalah paparkan aliran-aliran yang berhubungan dengan faktor-faktor yang mempengaruhi perkembangan peserta didik.

\section{Aliran Nativisme}

Tokoh aliran Nativisme adalah Schopenhauer. la adalah filosof Jerman yang hidup pada tahun 1788-1880. Aliran ini berpandangan bahwa perkembangan individu ditentukan oleh faktor bahwa sejak lahir (Syah, 2008:43). Konon juga dijuluki sebagai aliran pesimistis yang memandang segala sesuatu dengan kacamata hitam (Syah, 2008:43). Karena aliran ini berkeyakinan bahwa perkembangan manusia itu ditentukan oleh pembawannya. Aliran ini di dukung pendapatnya oleh aliran naturalisme yang dibidani oleh J.J Rousseau yang berpendapat bahwa: segala suci dari tangan Tuhan rusak ditangan manusia (Banjari, 2008:27). Faktor lingkungan kurang berpengaruh terhadap pendidikan dan perkembangan anak. Oleh karena itu, hasil pendidikan ditentukan oleh bakat yang dibawa sejak lahir. Dengan demikian, menurut aliran ini, keberhasilan belajar ditentukan oleh individu itu sendiri. Nativisme berpendapat jika anak memiliki bakat jahat dari lahir, ia menjadi jahat dan sebaliknya jika nak memiliki bakat baik, 
ia akan menjadi baik. Pendidikan anak yang tidak sesuai dengan bakat yang dibawa tidak akan berguna bagi perkembangan anak itu sendiri.

Pandangan ini tidak menyimpan dari kenyataan. Misalnya, anak mirip orang tuanya secara fisik dan akan mewarisi sifat dan bakat orang tua. Prinsipnya pandangan Nativisme adlah pengakuan tentang adanya daya asli yang telah terbentuk sejak manusia lahir kedunia, yaitu daya-daya psikologis dan fisiologis yang bersifat hederiter serta kemampuan dasar lainnya yang kepastiannya berbeda dalam diri tiap manusia. Ada yang tumbuh dan berkembang sampai pada titik maksimal kemampuannya, dan ada pula yang sampai hanya pada titik tertentu. Misalnya, seorang anak yang berasal dari orang tua yang ahli seni music, akan berkembang menjadi seniman music yang mungkin melebihi kemampuan orang tuanya, mungkin juga hanya sampai pada setengah kemampuan orang tuanya.

Coba simak cerita tentang anak manusia yang hidup dibawah asuhan serigala. la bernama Robinson Crussoe. Crussoe sejak bayi ia hidup deitengah hutan rimba yang belantara dan ganas, ia tetap hidup dan berkembang atas bantuan air susu serigala sebagai induknya. Serigala itu memberi Crussue makan sesuai selera serigala sampai dewasa. Akhirnya Crussue mempunyai gaya hidup, bicara, ungkapan bahasa, dan watak seperti serigala, padahal ia adalah anak manusia. Kenyataan ini pun membantah teori Nativisme sebab gambaran dalam cerita Robinson Crussoe itu telah membuktikan bahwa lingkungan dan didikan membawa pengaruh besar terhadap perkembangan anak.

Beberapa ahli biologi dan psikologi berpendapat bahwa peluang bagi para pendidik untuk memperoleh hasil pendidikan amat sedikit, tidak mengatakan tidak ada sama sekali. Boleh dikatakan tidak peluang untuk mendidik anak manusia. Mereka memandang bahwa evolusi anak seluruhnya di tentukan oleh hokumhukum pewarisan, sifat-sifat dan pembawaan orang tua dan nenek moyang mengalir sepanjang perkembangan, hingga sulit sekali mengubah melalui pendidikan (Darajat, dkk, 2008:51).

Psikolog Austria, H. Rohracher mengemukakan “... manusia hanyalah produk dari hokum proses alamiah yang berlangsung sebelum yang bukan buah dari pekerjaan dan bukan pula menurut keinginannya" (Darajat, dkk, 2008:51).

LL. Szondi menambahkan lebih jauh bahwa dorongan maupun tingkah laku social dan intelektual ditentukan sepenuhnya oleh faktor-faktor yang diturunkan (warisan) sebagai nasib yang menentukan seseorang (Darajat, dkk, 2008:51).

\section{Aliran Empirisme}

Toko aliran Empirisme adalah John Lock, filosof Inggris yang hidup pada tahun 1632-1704. Teorinya dikenal dengan Tabula rasa (meja lilin), dengan istilah lain berarti batu tulis kosong atau lembaran kosong (blank Slate/blank tablet) (Syah, 2008:44). Yang menyebutkan bahwa anak yang lahir ke dunia seperti tempat putih yang bersih. Kertas putih akan mempunyai corak dan tulisan yang digores oleh 
lingkungan. Aliran di sokong pendapatnya oleh J. F. Herbert dengan teori psikologi asosiasinya. la berpendapat bahwa jiwa manusia adalah kosong sejak dilahirkan baru akan berisi bila alat inderanya telah dapat menangkap sesuatu yang kemudian diteruskan oleh uart sarafnya masuk kedalam kesadaran, yaitu jiwa (Syah, 2008:28). Faktor bawaan dari orang tua (faktor turunan) tidak dipentingkan. Pengalaman diperoleh anak melalui hubungan dengan lingkungan (sosial, alam, dan budaya). Pengaruh empiris yang diperoleh dari lingkungan berpengaruh besar terhadap perkembangan anak. Menurut aliran ini, pendidik: sebagai faktor luar memegang peranan sangat penting, sebab pendidik menyediakan lingkungan pendidikan bagi anak, dan anak akan menerima pendidikan sebagai pengalaman. Pengalaman tersebut akan membentuk tingkah laku, sikap, serta watak anak sesuai dengan tujuan pendidikan yang diharapkan

Misalnya: suatu keluarga yang kaya raya ingin memaksa anaknya menjadi pelukis. Segala alat diberikan dan pendidik ahli didatangkan. Akan tetapi gagal, karna bakat melukis pada anak itu tidak ada. Akibatnya dalam diri anak terjadi konflik, pendidikan mengalami kesukaran dan hasilnya tidak optimal. Contoh lain, ketika dua anak kembar sejak lahir dipisahkan dan dibesarkan dilingkungan yang berbeda. Satu dari mereka dididik di desa oleh keluarga petani golongan miskin, yang satu dididik di lingkungan keluarga kaya yang hidup di kota dan disekolahkan di sekolah modern. Ternyata pertumbuhannya tidak sama. Kelemaha aliran ini adalah hanya mementingkan pengalaman. Sedangkan kemampuan dasar yang dibawah anak sejak lahir dikesampingkan. Padahal, ada anak yang berbakat dan berhasil meskipun lingkungan tidak mendukung.

\section{Aliran Konfergensi}

Tokoh aliran konfergensi adalah Wiliam Stem. la seorah tokoh pendidikan jerman yang hidup tahun 1871-1939. Aliran konferegensi merupakan kompromi atau kombinasi dari aliran Nativisme dan Emperisme. Aliran ini berpendapat bahwa anak lahir di dunia ini telah memiliki bakat baik dan buruk, sedangkan perkembanga anak selanjutnya akan dipengaruhi oleh lingkungan (Syah, 2008:46). Jadi, faktor pembawaan dan lingkungan sama-sama berperan penting. Anak yang membawa pembawaan baik dan didukung oleh lingkungan pendidikan yang baik akan menjadi semakin baik. Sedaangkan bakat yang dibawa sejak lahir tidak akan berkembang dengan baik tanpa dukungan lingkungan yang sesuai bagi perkenbangan bakat itu sendiri. Sebaliknya, lingkungan yang baik tidak dapat menghasilkan perkembangan anak secara optimal jika tidak didukung oleh bakat baik yang dibawa anak.

Dengan demikian, aliran konfergensi menganggap bahwa pendidikan sangat bergantung pada faktor pembawaan atau bakat dan lingkungan. Hanya saja, Wiliam Stem tidak menerangkan seberapa besar perbandingan pengaruh kedua 
faktor tersebut. Sampai sekarang pengaruh dari kedua faktor tersebut belum bias ditetapkan.

Apakah aliran konfergensi sebagaimana tersebut di atas dapat dijadikan pedoman dalam arti bahwa perkembangan peserta didik pasti bergantung pada pembawaan dan lingkungan pedidikannya? Sampai batad tertentu aliran ini dapat kita terima. Tetapi tidak secara mutlak. Sebab masih ada satu hal yang perlu diperhatikan yakni potensi psikologi tertentu yang juga tersimpan rapi dalam diri setiap peserta didik dan sulit diidentifikasi.

Hasil proses perkembangan peserta didik tak dapat dijelaskan dengan menyebutkan pembawaan dan lingkungan. Artinya keberhasilan seoarng peserta didik tidak hanya ditentukan oleh pembawaan dan lingkungan saja, karna peserta didik tersebut tidak hanya dikembangkan pembawaan dan lingkunganya, tetapi juga oleh didiri peserta didik sendiri. Setiap orang termasuk peserta didik tersebut memiliki potensi yang memungkinkan dirinya yang memungkinkan dirinya bebas memilih antara mengikuti atau menolak sesuatu (aturan atau stimulu ) lingkungan tertentu yang hendak mengembangkan dirinya. Alhasil, peserta didik sendiri memiliki potensi psikologis tersendiri untuk mengembangkan bakat dan pembawaannya dalam konteks lingkungan tertentu.

Dari kenyatann tersebut di atas, timbul pertanyaan dalam hal apa faktor pembawaan dan faktor lingkungan lebih menentukan?

Dari hasil pengelidikan yang dilakukan oleh para ahli psikologi diperoleh petunjuk sebagai berikut; faktor pembawaan lebih menentukan dalam hal intelgensi, fisik, reaksi pengindraan, sedangkan faktor lingkungan lebih menentukan dalam hal pembentukan kebiasaan, kepribadian, dan nilai nilai kejujuran, gembira, sedih dan ketergantungan kepada orang lain sangat dipengaruhi oleh belajar (training) (Darajat, dkk, 2008:129).

Kadar pengaruh keturuna (pembawaan) dan lingkungan terhadap peserta didik berbedaa sesuai dengan segi segi pertumbuhan kepribadian peserta didik. Kadar pengaruh kedua faktor ini juga berbedaa sesuai umur dan fase pertumbuhan yang dilalui. Faktor keturunan umumnya lebih kuat pengaruhnya pada tingkat bayi, yakni sebelum terjalinnya hunbungan social dan perkembangan pengalaman. Sebaliknya Ipengaruh lingkungan lebih besar pada manusia mulai dewasa, karna hubungan dengan lingkungan alam manusia, serta ruang geraknya sudah semakin luas (Darajat, dkk, 2008:55).

Karna itu Zakiah Drajat mengatakan bahwa tugas sekolah ialalh mempersiapkan semua unsur unsur kebudayaan untuk proses ini. Ada tiga hasil integrasi antara individu dengan lingkukngannya, perluasan, perbedaan. Dan penggabungan bahwa bila saja belajar benrlangsung maka yang belajar itu adalah seluruh organism manusia itu (Nasution, 2004:11).

Jalaluddin Rahmat dalam bukunya belajar cerdas, mengemukakan secara singkat para peneliti umumnya menilai perbandingan kedua pengaruh itu secara 
"fifti fifti" setengah disebabkan oleh keturunan dan setengahnya lagi oleh lingkungan. Jika IQ anda 20 poin, kira kira 120, 10 poin dari orang tua anda dan 10 poi lagi dari lingkungan (Rahmat, 2007:35). Lanjut beliau tetapi, yang paling penting adalah kecerdasan anda yang dibawah sebagai warisasn hanya anda miliki sebagai potensi. Ibarat rumah pembawaa adalah pondasi, sedangkan lingkungan adalah bangunan rumah.

Gerald Edelman, neorology pemenang nobel dan kepala The Neurological Instutute di The cripps clinik, la jolla, California mengemukakan neurology Darwinisme adalah teori yang menjelaskan bahwa otak memang harus plastis (lentur), yakni harus berubah ketika lingkungan dan pengalaman berubah. Itulah sebabnya mengapa kita harus menerima pelajaran (learn) dan juga bias menghilangkan pelajaran (anlearn) (Rahmat, 2007:175).

Jadi bahwa berbagai penelitian para ahli membuktikan bawaan saja tidak akan bias berkembang dan beruh kecuali ada faktor faktor lain diluar manusia itu sendiri yang mempengaruhinya. Akan tetapi, dalam hal pembawaan yang bersifat rohania sangat suli kita kenali. Banyak orang yang ahli dibidang " $X$ " tetapi anaknya ahli dibidang " $Y$ ". anak ini sudah di usahakan agar membelajari bidang " $X$ " supaya sama dengan orang tuanya, tetapi ia menolak dan menunjukkan kecendrungan bakat "Y"

Manusia lahir kedunia, dalam suatu lingkungan dengan pembawaan tertentu. Pembawaan yang potensial itu tidak spesifik melainkan bersifat umum dan dapat berkembang menjadi bermacam macam kenyataan antara interaksi dengan lingkungan. Pembawaan menentukan batas batas kemungkinan yang dapat dicapai oleh seseorang peserta didik akan tetapi lingkungan menentukan menjadi seseorang individu dalam kenyataan. Tentang fungsi pembawaan dan lingkungan Hendri G. Garret mengatakan sebagai berikut "jelaslah pembawaan dan lingkungan bukanlah hal yang bertentaangan melainkan saling membutuhkan" (Darajat, dkk, 2008:128).

Lingkungan yang buruk dapat merintangi pembawaan yang baik, tatapi lingkungan yang baik tidak dapat menjadi pengganti suatu pembawaan yang baik. Daerah yang penuh dengan kejahatan dan kesempatan latihan yang kurang, akan menimbulkan kebiasaan-kebiasaan yang buruk. Begitu juga lingkungan yang baik tidak dapat menjadikan peserta didik yang lemah pikiran menjadi orang yang pandai atau orang yang tidak berbakat menjadi berbakat. Karna itu ada fakror lain yang perlu diperhatikan oleh pendidik yaitu faktor dari diri peserta didik sendiri yang harus mengembangkan potensi dirinya secara maksimal, dengan memaksimalkan pembawaan dan pengaruh lingkungan dimana dia berada. Maka akan membawa peserta didik ke arah tujuan pendidikan. Dari aliran-aliran tersebut diatas ada dua aliran ekstrim yaitu pembawaan (Nativisme) dan lingkungan (Empirisme) sedang satu yang moderat yaitu penggabungan/kombinasi (Konvergensi). 
Perdebatan mengenai hal ini tidak akan pernah selesai. Karna dikolong langit dan diatas hamparan bumi, tak seorang pun yang bias memilih sebagai apakah ia akan dilahirkan. Termasuk juga memilih sebagai keturunan, suku, ras, bangsa, umat, dan warga Negara mana. Faktor keturuna merupakan sesuatu berpengaruh besar bagi pembawaan seseorang, setiap orang mewarisi gen (baik dan buruk) dari ayah, ibu, paman, bibi, kakek dan nenek mereka, melalui perpaduan sperma dan opum dari kedua orang tuanya.

Berdasarkan hal tersebut, Nabi Bersabda, Hadits ini saya kutip dalam bukunya Rachmat Ramadhani Al-Banjari yang berjudul "membaca kepribadian muslim seperti membaca Al-quran" yang berbunyi;

Kawinlah wanita yang baik, sebab sesungguhnya faktor gen keturunan itu kuat pengaruhnya" (H.R. Ibnu Adiy) (Banjari, 2008:120).

Hadis ini menekankan pentingnya bebet, bobot, dan bibit dalam memilih calon isteri atau bapak, karena akan menurunkan tabiat-tabiat, karakter, sifat bawaan kepada anaknya.

Begitu juga hanya lingkungan, Rasulullah SAW menekankan dalam sabdanya, "Jauhilah olehmu si cantik yang bearacun! Seorang sahabat bertanya; ya Rasulullah, siapa si cantic yang beracun itu? Rasul menjawab; perempuan yang cantik tetapi berada dalam lingkungan yang buruk" (H. P. Daruguthni) (Banjari, 2008:120).

Hadis ini mengandung makna bahwa kuatnya lingkungan dalam memberi pengaruh terhadap pembentukan pribadi anak. Oleh sebab itu baik faktor hediritas (keturunan) maupun faktor lingkungan, keduanya diakui saling mempengaruhi dalam membentuk pribadi, pola pikir, berkeyakinan, berperasaan, berperilaku, bersikap, berpenampilan dan bertindak manusia, hanya tidak ada kata sepakat para ahli mengenai faktor mana yang sangat domina, faktor keturunan atau lingkungan.

\section{KESIMPULAN}

Dalam pendidikan ada tujuan dan untuk mencapai tujuan memerlukan komponen-komponen pendidikan antara lain adalah pendidik dan peserta didik. Peserta didik adalah subyek dan obyek pendidikan, karena itu dalam proses belajar dan pembelajaran, seorang pendidik hendaknya memahami dan mengerti betul secara kompherensif mengenai eksistensi dan potensi peserta didiknya. Jika pemahaman yang kompherenshif oleh pendidik dan peserta didiknya, maka pendidikan akan berlangsung sesuai tujuan yang diinginkan.

Faktor-faktor yang mempengaruhi tinggi rendahnya hasil perkembangan peserta didik pada dasarnya ada 3 macam

1. Faktor intern yaitu faktor yang ada pada peserta didik itu sendiri yang meliputi pembawaan tertentu yang turut mengembangkan dirinya sendiri. 
2. Faktor ekstern yaitu hal-hal yang dating atau ada diluar peserta didik yang meliputi lingkungan (pendidikan) penagalaman berinteraksi peserta didik tersebut denagan lingkungannya.

3. Faktor potensi psikologis yang tersimpan pada diri peserta didik tersebut yang memungkinkan dia menerima atau menolak aturan atau stimulus lingkungan tertentu yang akan mengembangkan dirinya.

\section{DAFTAR PUSTAKA}

Al-Banjari, Rachmat Ramadhana, Membaca Kepribadian Muslim Seperti Membaca Al-Quran Cet. I; Jogyakarta: DIVA Perss,2008.

An-Nahlawi, Abdurrahman, Pendidikan Islam di Rumah: Sekolah dan masyarakat. Cet. IV; Jakarta: Gema Insan, 2004.

Darajat, Darajat, dkk, IImu Pendidikan Islam. Cet, VII; Jakarta: PT. Bumi Aksara, 2008

Darajat, Darajat, Metodik Khusus Pengajaran Agama Islam. Cet, IV; Jakarta: PT. Bumi Aksara, 2008.

Darajat, Darajat, Metodologi Pengajaran Agama Islam. Cet, III: Jakarta: Bumi Aksara 2008.

Isa, Kamal Muhammad, Manajemen Pendidikan Islam, Cet; I; Jakarta: PT. Fikahati Aneska, 1994

Langgulung, Hasan, Manusia Pendidikan: Suatu Analisis Psikologis, Filsafat dan pendidikan. Cet. V. Edisi Revisi; Jakarta: Pustaka Al-Husna, 2004.

Langgulung, Hasan, Pendidikan Islam Dalam Abad ke 21. Cet, III. Edisi Revisi; Jakarta: Pustaka Al-Husna Baru, 2003.

Nizar, Samsul, Filsafat Pendidikan Islam, Pendekatan Historis, Teoritis, dan Praktis. Cet; I; Jakarta: PT. Intermesa, 2002

Rahmat, Jalaluddin, Belajar Cerdas, Belajar Berbasiskan Otak. Cet, VII; Bandung; Mizan Learning Centre, 2007

Syah, Muhibbin, Psikologi Pendidikan, Dengan Pendekatan Baru. Cet. XIV; Jakarta: PT. Remaja Rosdakarya, 2008. 